\title{
Review: Poetry
}

Author(s): D. A. M.

Review by: D. A. M.

Source: The Celtic Review, Vol. 10, No. 39 (Nov., 1915), pp. 284-285

Stable URL: http://www.jstor.org/stable/30070351

Accessed: 21-06-2016 19:36 UTC

\section{Your use of the JSTOR archive indicates your acceptance of the Terms \& Conditions of Use, available at}

http://about.jstor.org/terms

JSTOR is a not-for-profit service that helps scholars, researchers, and students discover, use, and build upon a wide range of content in a trusted digital archive. We use information technology and tools to increase productivity and facilitate new forms of scholarship. For more information about JSTOR, please contact support@jstor.org. 
P. 512. 'Winchester, Ptolemy Venta ... in W. Caer Gevent, fort, castle on the plain, clearing or open country.' Here again gwent is the Welsh form of Venta, a market-place.

P. 325. 'Kent, 55 B.C., Cantium. ... Cf. W. gwyn, gwen [white]. Possibly it means headland; cf. G. ceann, head, and Gabrosenti, O. Kelt. form of Gateshead.' In 55 B.c. the modern Welsh gwyn would have appeared as vindos, so that any connection between Cantium and W. gwyn is out of the question. Gaelic ceann is equally impossible, unless the author is prepared to claim a Gaelic element in the south of England; even then the vowel of Cant- would require to be $e$, and what of the $t$ ? Mr. Johnston appears to think that in Gabrosenti the latter part senti means 'head.'

So far as the Celtic names are concerned, the value of Mr. Johnston's book consists in the lists themselves, the old forms, and the occasional derivations (e.g. of Aeron) by Celtic scholars; except in the case of straightforward names, which bear their meaning on the surface, the author's philological equipment in Celtic is inadequate. The above criticism of course affects only a small part of the whole work, the great bulk of which is devoted to the explanation of names of Teutonic origin. W. J. W.

\section{Poetry}

Svold: A Norse Sea Battle. By S. F. B. Lane. London: David Nutt. 2s. $6 d$. net.

The story is told in blank verse which is unaffected and runs smoothly, and is not pitched on a level too high for the poet. In the clamour of battle Mr. Lane is at his best :-

Ever the uproar sounded in their ears,

The staggering feet, the shouts of striving men,

The rush of arrows and the grinding swords,

And the wild crash of are on splintering shield.

This battle was fought between Olaf Tryggvason, King of Norway, and the combined fleets of King Srein of Denmark, King Olaf of Sweden, and Earl Eric. Olaf fell and all his ships were annihilated. Mr. Lane's notes are at once scholarly and exhaustive, and reveal him as a close student of Scandinavian literature and antiquities.

England Overseas. By LLOYD RoBERTs. London : Elkin Mathews. 2s. 6 d. net.

Mr. Roberts is one of those English poets who show traces of the influence of contemporary Celtic verse. There are also echoes of Kipling, who is half Celtic, for his mother was a MacDonald from Skye. As most of England's patriotic poems have been written by Scotsmen, like Campbell and 
Thomson and the half Scots Kipling, it is refreshing to find an Englishman (with, however, a Welsh name) singing so heartily :-

England's cliffs are white like milk,

But England's fields are green ;

The grey fogs creep across the moors,

But warm suns stand between.

And not so far from London town, beyond the brimming street,

A thousand little summer winds are singing in the wheat.

D. A. M.

\section{NOTES}

Note on newly-found Tain Place-Names. - Some old parchments collected by the late Harry M. Taylor, once Town Clerk of Tain, and then SheriffSubstitute, and which on his death passed to the late Dr. Taylor Innes, having been sent to me here to be read, the first taken proves to be of some interest. It is a Latin charter of 1577 , and recites that Thomas Ratray, indweller (convicinus) of the town of Tain, grants to Alexander $M$ Finlay Duf lands, with buildings, viz. the west half of a croft called Croft Neganich, of old belonging to John M'Ean Orangich, extending to three or four acres (ad seminaturam sex firlotarum hordei) lying in the north part of the burgh, having the mound (montem) called the Angel Hill on the east, the common way that leads to Plaids on the west, the 'Laik' on the north, and the common way that leads to the Chapel (sasellum, evidently for sacellum) of the Blessed Duthac on the south. Also half of a croft called Croft called Clasthena Vorik, extending to about an acre or more (quinque peckis sive majore), having the lands of the Chaplain of the Blessed Duthac on the east, the mound called Angel Hill on the west, the burn (torrentem seu lie Laik) or Laik on the north ; also half share of three cottages, etc. Reddendo to the clergy of the Blessed Duthac the usual yearly rent. Witnesses, Andrew Ross and John Reid, burghers; Donald Reid, John Moir M'Kessack and Donald Davidson, officer. Of above names, Neganich is a phonetic spelling of na gainmhich, 'of the sand,' i.e. 'Sand-croft.' Clasthena Vorik is Clais nam moraich, 'Hollow of the fishers,' or Claisean a' mhoraich, 'Little hollow of the fisher,' both according to Professor Watson. The Angel Hill-the origin or reason of which name is unknown-was cut away when the railway was formed, and was close to the bridge which preserves the name. The first croft, to west of it, would cover the present railway station and yard site and the adjacent part of the Links, which ground exactly answers the description of 'sandy.' The other croft to east of it lay at the mouth of a trout stream, and a place where small fishing boats could easily be sheltered or drawn up was a most likely place for the abode of a fisher or fishers. North of both was 'the burn or laik.' This is temptingly like the English 'lake,' and at the height of the tide there is-now, at any rate-an expansion a little above. But within living memory the 'way to Plaids' was still 